\title{
Sensory Transduction in Vomeronasal Neurons: Evidence for Gao, Gai2, and Adenylyl Cyclase II as Major Components of a Pheromone Signaling Cascade
}

\author{
Anna Berghard and Linda B. Buck \\ Department of Neurobiology, Howard Hughes Medical Institute, Harvard Medical School, Boston, Massachusetts 02115
}

The mammalian vomeronasal organ (VNO) is an accessory olfactory structure implicated in the sensing of pheromones. Although virtually nothing is known about sensory transduction in the mammalian VNO, recent findings have raised the possibility that it proceeds via a G-protein-coupled mechanism and involves a cyclic nucleotide-gated ion channel as in the nasal olfactory epithelium. To investigate this possibility, we cloned G-protein $\alpha$ subunits, adenylyl cyclases, and guanylyl cyclases that are expressed in the VNO and examined their patterns of expression. Of seven $\mathrm{G} \alpha$ subunits identified as being expressed in the VNO, we found that mRNAs encoding only two, $\mathrm{G} \alpha \mathrm{O}$ and $\mathrm{G} \alpha \mathrm{i} 2$, are highly expressed in VNO neurons. More-

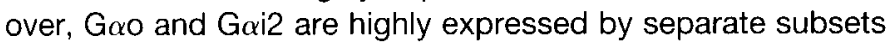
of neurons that are located in different regions of the VNO neuroepithelium. Immunohistochemical studies show that both G $\alpha O$ and $\mathrm{G} \alpha \mathrm{i} 2$ are enriched in VNO microvilli, suggesting that G-proteins containing both of these $\alpha$ subunits may be involved in VNO sensory transduction. Of the adenylyl and guanylyl cyclases that we cloned, we found that only one, adenylyl cyclase type II, is highly expressed in VNO neurons; furthermore, it is expressed by both $\mathrm{G}_{\alpha O}{ }^{+}$and $\mathrm{G} \alpha \mathrm{i}{ }^{+}$subsets. Our findings suggest that spatially segregated subsets of VNO neurons may use different, but related, sensory transduction pathways in which G-proteins and an adenylyl cyclase play major roles.

Key words: vomeronasal; G-protein; olfactory; signal transduction; chemosensory; adenylyl cyclase; pheromone; Jacobson's organ
In the mammalian olfactory system, environmental stimuli are detected by sensory neurons at two locations: the nasal olfactory epithelium (OE) and the vomeronasal organ (VNO) (Shepherd, 1988). Volatile odorants are detected in the $\mathrm{OE}$, whereas the VNO appears to specifically detect pheromones, molecules released from one member of a species that can induce innate social or sexual behaviors and neuroendocrine changes in conspecifics (Keverne, 1983; Halpern, 1987; Wysocki and Meredith, 1987).

The VNO is a tubular structure at the base of the nasal septum that opens into the nasal cavity. The VNO neurocpithclium and $\mathrm{OE}$ have a common embryological origin and a similar structure (Cuschieri and Bannister, 1975). OE and VNO sensory neurons resemble one another in morphology, lifespan, and axonal projection, and both express olfactory marker protein (OMP) (Barber and Raisman, 1978; Farbman and Margolis, 1980). These similarities suggest that, although VNO and OE neurons may detect different ligands, they may use similar strategies for transducing sensory signals and transmitting those signals to the brain.

In the mammalian $\mathrm{OE}$, odorants bind to odorant receptors on sensory neurons, thereby inducing a transduction cascade in which

\footnotetext{
Received Sept. 6, 1995; revised Oct. 23, 1995; accepted Oct. 31, 1995.
}

This work was supported by grant 1-RO1-DC01662-01 from National Institutes of Health (L.B.B.), the W. M. Keck Foundation [the Joint Structural Neurobiology Program (L.B.B.)], the McKnight Endowment Fund for Neuroscience (L.B.B.), the John Merck Fund (L.B.B.), the Swedish Natural Science Research Council (A.B.), and lle Swedisl Institute (A.B.). L.B.B. is a Iloward Ilughes Medical Institute Assistant Investigator. We thank all members of the Buck lab for helpful scientific discussions and lechnical advice. We thank Christine Sadlowski and Ashi Hafeez for their expert technical assistance, and Linnea Krizsan for help in preparing this manuscript.

Correspondence should be addressed to Dr. L. Buck, Howard Hughes Medical Institute, Department of Neurobiology, Harvard Medical School, 2)0 I ongwood Avenue. Boston, MA 02115

Copyright $\odot 1996$ Society for Neuroscience $0270-6474 / 96 / 160909-10 \$ 05.00 / 0$ interactions of a $\mathrm{G} \alpha$ s-like G-protein, Goolf, with adenylyl cyclase type III (AC III) induces elevations in cAMP that open cyclic nucleotide-gated (CNG) ion channels (Reed, 1992; Ronnett and Snyder, 1992; Breer et al., 1994; Zufall et al., 1994; Buck, in press). Inositol triphosphate $\left(\mathrm{IP}_{3}\right)$ may also increase, but its role is unclear.

In contrast, virtually nothing is known about sensory transduction in the mammalian VNO. We recently found that one subunit (oCNC2) of the olfactory CNG channel is expressed in mouse VNO neurons, but that Goolf, AC III, and another channel subunit (OCNC1) are not (Berghard et al., in press). 'T 'his indicated that VNO sensory transduction differs from that in the OE, but that it might involve CNG channels that, as in the OL, are opened by CAMP after the activation of a G $\alpha$ s-like G-protein. On the other hand, studies in snake and turtle indicate that VNO sensory transduction may, at least in some species, involve $\mathrm{IP}_{3}$ increases mediated by a $\mathrm{G}$-protein resembling G $\alpha 0$, G $\alpha$, or G $\alpha q$ (Luo et al., 1994; Taniguchi et al., 1995). Immunohistochemical studies indicate that a number of G-proteins ( $\mathrm{G} \alpha \mathrm{o}, \mathrm{G} \alpha \mathrm{s}, \mathrm{G} \alpha \mathrm{i} 2$, and $\mathrm{G} \alpha \mathrm{q} / \mathrm{G} \alpha 11)$ are present on rat VNO axons; however, this need not imply a role in sensory transduction, as emphasized by the presence of several G-proteins, but not Goolf, on OE axons (Menco et al., 1992, 1994; Shinohara et al., 1992b).

To identify potential VNO sensory transduction components, we searched for G-proteins, and adenylyl and guanylyl cyclases, that are highly expressed in mouse VNO neurons. Consistent with a recent immunohistochemical study in opossum (Halpern et al., 1995), our studies suggest the existence of two G-protein-

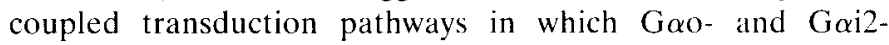
containing G-proteins play major roles. Our studies further identify adenylyl cyclase type II (AC II) as a likely component of both pathways. 


\section{MATERIALS AND METHODS}

Cloning procedures. A cDNA library was prepared using polyA ${ }^{+}$RNA isolated from male and female C57BL/6J VNO according to standard procedures (Sambrook et al., 1989) in $\lambda$ ZAPII (Stratagene, La Jolla, CA). PCR was carried out in $10 \mathrm{~mm}$ Tris- $\mathrm{HCl}, \mathrm{pH} 8.3,50 \mathrm{~mm} \mathrm{KCl}, 1.5 \mathrm{~mm}$ $\mathrm{MgCl}_{2}, 0.001 \%$ gelatin, $200 \mu \mathrm{M}$ each of dATP, dCTP, dGTP, and dTTP, $1 \mathrm{U}$ of Taq polymerase (Boehringer, Indianapolis, IN), and $2 \mu \mathrm{M}$ of each primer with $1 \mu \mathrm{l} / 10 \mu \mathrm{l}$ reaction of cDNA generated from $0.1 \mu \mathrm{g} / \mu \mathrm{l}$ total VNO RNA (pretreated with DNase RQI; Promega, Madison, WI) using random hexamer primers (Buck and Axel, 1991). Amplifications were according to the following schedule: $96^{\circ} \mathrm{C}$ for $45 \mathrm{sec}, 45^{\circ} \mathrm{C}$ for $3 \mathrm{~min}$, and $72^{\circ} \mathrm{C}$ for 3 min with $6 \mathrm{sec}$ extension for 50 cycles. Alternatively, $1 \mathrm{ng} / \mu \mathrm{l} \lambda$-DNA from the VNO cDNA library, representing $10^{4}$ or $10^{5}$ pfu, was used in PCR reactions for 40 cycles. The $5^{\prime}$ primers for $\mathrm{G} \alpha$ subunits were as follows: P41, 5'-GGIAA(A/G)(A/T)(G/C)IACITT(T/C)(C/A)TIAA(A/G)CA(A/G)ATG-3'; P42, 5'-GGIAA(G/A)AG(T/C)ACIATIGTIAA(G/A)CA(G/A)ATG-3'. The 3' primers had the following sequences: $\mathrm{P} 43,5^{\prime}-(\mathrm{T} / \mathrm{C})(\mathrm{T} / \mathrm{C})$ ITGICCICCIAC(G/A)TC(G/A)AA(G/C)AT-3'; P44, $5^{\prime}-\mathrm{T}(\mathrm{C} / \mathrm{G}) \mathrm{I}(\mathrm{T} / \mathrm{G})(\mathrm{C} / \mathrm{A}) \mathrm{IC}(\mathrm{T} / \mathrm{G})(\mathrm{C} /$ T)TGICCICCIAC(G/A)TC-3'. The $\sim 480$ bp PCR products were gelisolated and cloned into pBluescript SK (Stratagene). Unique clones first were identificd by restriction enzyme digestion of PCR-amplified inserts of individual colonies and then sequenced (Ressler et al., 1993). The Gos product isolated contained a sequence encoding the amino acids EGGEEDPQAARSNSDGE, which is representative of one out of four splice variants described for this gene (Bray et at., 1986). The cloned firs sequence should recognize, however, all four $\mathrm{G} \alpha \mathrm{s}$ variants when used as a probe. The vomeronasal cDNA library $\left(3 \times 10^{5} \mathrm{pfu}\right)$ was screened with the reverse transcription (RT)-PCR products obtained after ${ }^{32} \mathrm{P}$ labeling using a random priming procedure (Stratagene). The same filters then were reprobed with a mix of ${ }^{32} \mathrm{P}$-labeled $\mathrm{G} \alpha \mathrm{i} 2, \mathrm{G} \alpha \mathrm{o}, \mathrm{G} \alpha \mathrm{s}$, and $\mathrm{G} \alpha 13$ (for hybridization conditions, see Northern analysis). This yiclded a hybridization pattern that was identical to that obtained with the RT-PCR products. Two independent Goo cDNA clones were isolated and sequenced with a primer (5'-AACCACGAACCGCATGCACG-3'), which revealed that GooA was present in the vomeronasal cDNA library. To amplify the G $\alpha q$ class specifically, the following primers each were used together with $\mathrm{P} 41$, using the same PCR conditions as described above: P51, 5'-AAGA(A/G)GGC(C/T)TTG(G/C)(A/T)(C/T)TC(CT)TCCAT-3'; P52, 5'-TC(T/C)TCGA(G/A)(G/A)CA(T/C)TG(A/G)TC(G/A)TA(C/T)TC-3'. For amplification of $\mathrm{G} \alpha q$, specific primers were (P55) 5'-ACCTTCATCAAGCAGATGAGG-3' and (P56) 5'-ACCATTCTGAAAATGACACTTTGT-3', which were used in the PCR protocol outlined above with the exception that the annealing temperature used was $65^{\circ} \mathrm{C}$. The same RT-PCR protocol outlined above was used (annealing temperature $45^{\circ} \mathrm{C}$ ) using primers that would recognize AC cDNAs: P47, 5'-ATIAA(G/A)ACIAIIGGi(A/T)(G/C)IACITA(C/T)ATG-3'; P48, 5'TTIACIGTITTICCCCA $(A / G) T C(A / G) T A-3{ }^{\prime}$. The PCR product obtained was ${ }^{37} \mathrm{P}$-labeled and used to screen $3 \times 10^{5}$ pfu from the VNO cDNA library at $65^{\circ} \mathrm{C}$, which represents moderately stringent hybridization conditions. From this screen, ACs II and VII were obtained. These were partially sequenced, revealing that the $\mathrm{AC}$ II clone started at a site equivalent to 2136 in the rat AC II (Genbank accession number M80550). AC VII started at 3602 of the mouse AC VII sequence in Genbank (accession number U12919). We are grateful to Dr. F. L. Margolis (Roche Institute, Nutley, NJ) for the OMP clone, which has becn described previously (Danciger et al., 1989; Ressler et al., 1993).

RNA preparation and Norhern analysis. The VNO of adult male C56BL/6J mice (Jackson Labs, Bar Harbor, ME) were dissected out, and only tissue inside the encapsulating bone was collected. OE, whole brain, kidney, and VNO tissues were frozen immediately in $\mathrm{N}_{2}$ (liquid) and stored at $-80^{\circ} \mathrm{C}$ until total RNA was prepared as described previously (Cathala et al., 1983). PolyA ${ }^{+}$RNA was prepared using oligo-dTcellulose (Stratagene). PolyA ${ }^{+}$RNA was fractionated through formaldehyde $1.0 \%$ agarose gels, blotted onto nylon membrane (Amersham, Arlington Heights, IL), and fixed by ultraviolet irradiation (Stratagene) (Sambrook et al., 1989). Both a total RNA sample and a molecular weight marker $(0.24-9.5 \mathrm{~kb}$; Gibco, Grand Island, NY) were run on the same gel for sizc detcrmination. Filters were prehybridized and hybridized in $0.5 \mathrm{M}$ phosphate buffer, $\mathrm{pH} 7.3$, with $1 \%$ bovine scrum albumin and $4 \%$ SDS. Inserts of cloned sequences were ${ }^{32} \mathrm{P}$-labeled by random priming. The following probes were used in hybridizations at $80^{\circ} \mathrm{C}$ (very high stringency): G $\alpha$ o, G $\alpha$ i2, G $\alpha$ s, and AC II. Hybridization temperature for the OMP probe was $70^{\circ} \mathrm{C}$. For quantitation of the relative intensities of hybridization signals, a PhosphorImager (Molecular Dynamics, Sunnyvale, CA) was used.

In situ hybridization. The procedure we used was as described previ- ously (Sassoon et al., 1988; Ressler et al., 1993). Briefly, adult C57BL/6J mice (Jackson Labs) were anesthetized with $1.25 \%$ 2,2,2-tribromocthanol and $0.775 \%$ amyl alcohol and then perfused intracardially with cold PBS followed by $4 \% p$-formaldehyde in PBS (fix). After isolation, tissue was incubated overnight at $4^{\circ} \mathrm{C}$ in the fix and then decalcified for $4 \mathrm{~d}$ at $4^{\circ} \mathrm{C}$ in fix/0.215 M EDTA. For study of VNO development, pregnant C57BL/6J mice were obtained from Charles River Laboratories (Wilmington, MA) and pups were killed at the indicated days after birth (P1 denotes day of birth). Tissue was isolated and fixed overnight at $4^{\circ} \mathrm{C}$ in $p$-formaldehyde. The tissue was dehydrated and embedded into paraffin according to standard procedures before sectioning. Sections were arranged onto $0.01 \% \mathrm{Cl}^{3+} / 0.2 \%$ gelatin-coated glass slides and treated, hybridized, and washed as detailed in Sassoon et al. (1988). ${ }^{35}$ S-Labeled RNA probes (Stratagene) were diluted to $35,000 \mathrm{cpm} / \mathrm{ml}$ in hybridization solution containing $50 \%$ deionized formamide, $0.3 \mathrm{M} \mathrm{NaCl}, 20 \mathrm{~mm}$ Tris- $\mathrm{HCl}, \mathrm{pH} 7.4,5 \mathrm{~mm}$ EDTA, $10 \mathrm{~mm} \mathrm{NaPO}, \mathrm{pH} 8.0$, $10 \%$ dextran sulfate, $1 \times$ Denhardt's solution, and $50 \mu \mathrm{g} / \mathrm{ml}$ yeast RNA. After hybridization for $16-18 \mathrm{hr}$ at $52^{\circ} \mathrm{C}$, slides were washed in $50 \%$ formamide, $2 \times$ SSC, $\mathrm{O} .1 \mathrm{M}$ dithiothreitol at $65^{\circ} \mathrm{C}$, then rinsed in $0.4 \mathrm{M} \mathrm{NaCl}, 0.1 \mathrm{M}$ Tris- $\mathrm{HCl}, \mathrm{pH} 7.5$, and $0.05 \mathrm{M}$ EDTA, treated with RNase A $(20 \mu \mathrm{g} / \mathrm{ml}$; Boehringer) for $30 \mathrm{~min}$ at $37^{\circ} \mathrm{C}$ and, finally, washed once in $2 \times \mathrm{SSC}$ and once in $0.1 \times \mathrm{SSC}$ at $37^{\circ} \mathrm{C}$ for $15 \mathrm{~min}$ each. Slides were dehydrated and processed for autoradiography using NBT-2 photographic emulsion (Kodak, Rochester, NY). Exposure times were as indicated in the figure legends. Hoechst 33258 was used as histological stain. Images were processed using Adobe Photushop version 3.0.

Immunohistochemistry. Three-week-old mice were perfused intracardially as described above using Bouin's fixative $(4.8 \%$ acetic acid, $2.4 \%$ formaldehyde, and $71.4 \% \mathrm{H}_{2} \mathrm{O}$ saturated with picric acid), and the dissected tissue was post-fixed for $4 \mathrm{hr}$, cryoprotected by incubation in $30 \%$ sucrose, and frozen in O.C.T. compound (Miles, Elkhart. IN) before it was sectioned at $10 \mu \mathrm{m}$ using a cryostat. Specific immunoreactivity was detected by the biotin-avidin-horseradish peroxidase method ( $\mathrm{ABC}$ Elite) as recommended by the supplier (Vector, Burlingame, CA). Triton $\mathrm{X}-100(0.1 \%)$ was included in all steps except those involving the peroxidase enzyme. Primary antibodies used were affinity-purified rabbit antiG $\alpha 0$ (Upstate Biotechnology, Lake Placid, NY) and rabbit anti-Goi (immunogen was a peptide corresponding to amino acids $345-354$ of rat Goi3; Santa Cruz Biotechnology, Santa Cruz, CA), which recognizes all known $\mathrm{G} \alpha \mathrm{i}$. Anti-G $\alpha 0$ was used at a concentration of $0.062 \mu \mathrm{g} / \mathrm{ml}$, and anit-G $\alpha$ i was used at $0.01 \mu \mathrm{g} / \mathrm{ml}$. Incubation with primary antibodies was done overnight at $4^{\circ} \mathrm{C}$. Omitting the primary antibody from the staining procedure caused no detectable staining in either olfactory or VNO neuroepithelia.

\section{RESULTS}

\section{Identification of Ga subunits expressed in the VNO}

The goal of the present studies was to identify molecules that might be involved in sensory transduction in mammalian VNO neurons. Northern blutling, immunohistochemistry, cDNA library screens, and in situ hybridization indicate that presumed components of the transduction pathway of OE neurons are highly expressed in those cells. This high-level expression of signaling components likely maximizes the rate of sensory signaling (Lamb and Pugh, Jr., 1992) and suggests that sensory transduction molecules in VNO neurons are also likely to be highly expressed.

In initial experiments, we asked whether there is a specific $\mathrm{G}$-protein $\alpha$ subunit that is highly expressed in VNO neurons. To scarch for $\mathrm{G} \alpha$ subunits expressed in VNO neurons, we first used PCR to amplify $G \alpha$-coding sequences present in mouse VNO RNA. Random-primed cDNA prepared from VNO RNA, or DNA prepared from a VNO cDNA library, was subjected to PCR with degenerate oligonucleotide primers that match conserved amino acid stretches in the $\mathrm{G} \alpha$ protein family. In these experiments, two different $5^{\prime}$ primers and two $3^{\prime}$ primers were used in all possible combinations. Theoretically, these primer combinations should permit the amplification of sequences encoding all $\mathrm{G} \alpha$ subunits thus far identified (Neer, 1995). The PCR products were cloned into a plasmid vector, and unique clones were identified by digestion with restriction enzymes. Sequence analyses of the 
unique clones showed that they encoded segments of five different $\mathrm{G} \alpha$ subunits: $\mathrm{G} \alpha \mathrm{s}, \mathrm{G} \alpha \mathrm{o}, \mathrm{G} \alpha \mathrm{i} 2, \mathrm{G} \alpha 13$, and $\mathrm{G} \alpha 14$.

We next examined whether there might be additional $\mathrm{G} \alpha$ subunits represented in the PCR products that we had not cloned, but that are abundantly expressed in the VNO. To do this, we first screened filters prepared from a VNO cDNA library with a probe containing a mix of the original PCR products. We then stripped the filters to remove the probe and rehybridized the filters to a mix of the cloned $\mathrm{G} \alpha$ sequences that we had isolated already. The patterns of hybridization obtained with the two probes were identical. Although we cannot exclude absolutely that there are additional $\mathrm{G} \alpha$ subunits abundantly expressed in the VNO, this result argues strongly against that possibility. Of note, G $\alpha$ olf, which is implicated in sensory transduction in the OE, was not represented among the sequences we cloned.

Among the $\mathrm{G} \alpha$ clones that we obtained, only one, $\mathrm{G} \alpha 14$, belonged to the $\mathrm{G} \alpha \mathrm{q}$ class of $\mathrm{G} \alpha$ subunits, which causes increases in $\mathrm{IP}_{3}$ by stimulating phospholipase $\mathrm{C}$ (PLC). However, immunohistochemical studies with antibodies that recognize $\mathrm{G} \alpha \mathrm{q}$ and $\mathrm{G} \alpha 11$, another member of the $\mathrm{G} \alpha \mathrm{q}$ class, indicate that $\mathrm{G} \alpha \mathrm{q}$ and/or G $\alpha 11$ is present in VNO sensory axons (Menco et al., 1994). To search for additional members of the $\mathrm{G} \alpha \mathrm{q}$ class that might be expressed at a lower level in the VNO, we performed additional PCR experiments using primers more specific for members of the $\mathrm{G} \alpha \mathrm{q}$ class (i.e., $\mathrm{G} \alpha \mathrm{q}, \mathrm{G} \alpha 11, \mathrm{G} \alpha 14, \mathrm{G} \alpha 15$, and $\mathrm{G} \alpha 16$ ). This effort yielded one additional $\mathrm{G} \alpha$ subunit, $\mathrm{G} \alpha 11$. Yet another set of primers specific for $\mathrm{G} \alpha \mathrm{q}$ had to be used to amplify $\mathrm{G} \alpha \mathrm{q}$ from VNO cDNA.

\section{Distinct patterns of high-level $\mathrm{G} \alpha \mathrm{o}$ and $\mathrm{G} \alpha \mathrm{i} 2$ expression in the VNO neuroepithelium}

To determine whether any of the Ga sequences we had cloned is highly expressed in VNO neurons, we performed in situ hybridization experiments in which we hybridized radiolabeled probes prepared from the $\mathrm{G} \alpha$ clones to tissue sections cut through the VNO. Each probe was also hybridized to sections through the OE of the nasal cavity. As a reference, we used a probe prepared from a cloned segment of the OMP gene (Danciger et al., 1989). OMP is expressed in all mature neurons in both the VNO and OE (Farbman and Margolis, 1980; Monti-Graziadei et al., 1980).

The results of these experiments indicate that two different $\mathrm{G} \alpha$ subunits, G $\alpha$ o and $\mathrm{G} \alpha \mathrm{i} 2$, are highly expressed in VNO neurons (Fig. 1A). High expression of RNAs encoding these two subunits is observed primarily in separate subpopulations of VNO neurons, which are located in distinctly different regions of the neuroepithelium. High expression of $\mathrm{G} \alpha \mathrm{o}$ is observed in neurons in the basal (lower) half of the epithelium, whereas high expression of $\mathrm{G} \alpha \mathrm{i} 2$ is observed in neurons in the apical (upper) part of the neuroepithelium that lies closer to the epithelial surface. Neither subunit is highly expressed in supporting cells, which form an uppermost apical layer of cells. Two parallel zones showing high G $\alpha$ o or G $\alpha$ i 2 expression run along the length of the VNO neuroepithelium. Each zone has an undulating appearance, apparently because of the presence of blood vessels toward the base of the neuroepithelium.

Closer examination indicates that along most of the dorsalventral length of the VNO epithelium, there is little or no overlap between the VNO subsets expressing G $\alpha$ o and G $\alpha$ i2 (Fig. 1B). However, at the dorsal and ventral extremes of the neuroepithelium, the patterns of $\mathrm{G} \alpha \mathrm{o}$ and $\mathrm{G} \alpha \mathrm{i} 2$ hybridization are overlapping. Previous studies indicate that, in the adult animal, these terminal regions contain the progenitors of VNO neurons and that the
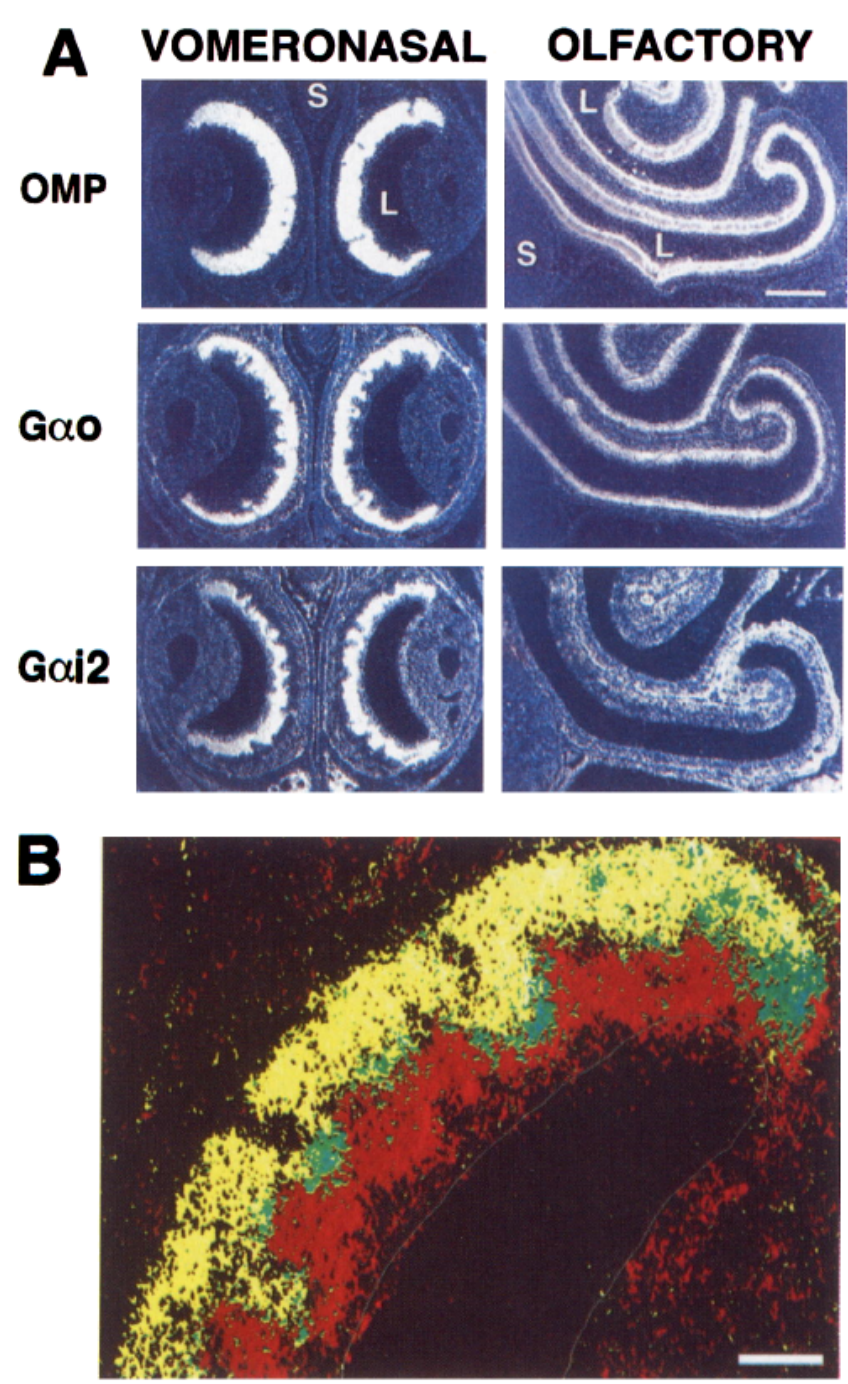

Figure 1. G $\alpha$ o and G $\alpha \mathrm{i} 2$ mRNA expression in the VNO and OE. $A$, Sequential coronal sections through the VNO and OE were hybridized with probes prepared from coding region segments of $G \alpha o$, Goi2, or OMP cDNA. In the VNO neuroepithelium, the OMP probe hybridizes to all mature neurons, but not to the most apical layer of cells closest to the lumen $(L)$, which are supporting cells. Both the $\mathrm{G} \alpha \mathrm{O}$ and $\mathrm{G} \alpha \mathrm{i} 2$ probes show intense hybridization to VNO neurons, but $\mathrm{G}_{\alpha \mathrm{o}^{+}}$neurons have a more basal, and $\mathrm{G}_{\alpha \mathrm{i}}{ }^{+}$neurons have a more apical, location. $\mathrm{G} \alpha \mathrm{O}^{+}$and $\mathrm{G} \alpha \mathrm{i} 2^{+}$neurons appear to occupy two distinct zones that run parallel to each other along the length of the neuroepithelium, but have an undulating appearance because of the presence of blood vessels. In the OE, the OMP probe hybridizes intensely to all neurons, as expected. The G $\alpha$ o probe also appears to hybridize to all neurons, whereas the Gai2 probe does not hybridize any more intensely to OE neurons than to other cell types. Autoradiographic exposure was for 2 weeks. $S$, Nasal septum. Scale bar, $250 \mu \mathrm{m}$. $B$, Higher-magnification photographs of consecutive sections hybridized with the G $\alpha \mathrm{o}$ and G $\alpha$ i2 probes were superimposed using Adobe Photoshop version 3.0. The Goo hybridization signal is shown in

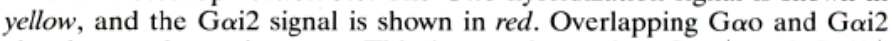
signals are shown in green. This image shows that $\mathrm{G} \alpha \mathrm{o}^{+}$and $\mathrm{G} \alpha \mathrm{i}^{+}$ neurons occupy distinct zones of the VNO neuroepithelium, which are almost mutually exclusive except at the dorsal and ventral termini, where they overlap completely. Scale bar, $50 \mu \mathrm{m}$.

offspring of the progenitors migrate inward from the termini (Barber and Raisman, 1978; Monti-Graziadei et al., 1980). The high expression of $\mathrm{G} \alpha \mathrm{o}$ and $\mathrm{G} \alpha \mathrm{i} 2$ in the termini could reflect the presence of both subunits in individual progenitors or immature neurons or, alternatively, could be caused by an intermingling of 


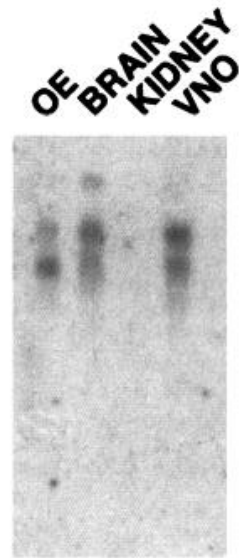

Gao
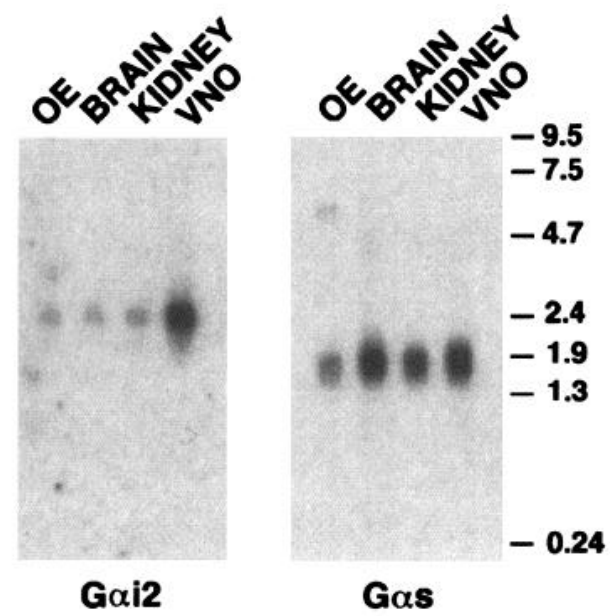

Figure 2. Northern blot analyses of $G \alpha o, G \alpha i 2$, and $G \alpha s$ expression in the VNO and OE. PolyA ${ }^{+}$RNAs obtained from mouse OE, brain, kidney, and VNO were analyzed. One microgram of polyA ${ }^{+}$RNA was loaded per lane. The VNO and OE samples show comparable amounts of $\mathrm{G} \alpha \mathrm{O}$ and similar G $\alpha$ o message sizes. In contrast, the VNO sample shows a 10-fold higher level of $\mathrm{G} \alpha \mathrm{i} 2$ than any of the other tissues examined. Hybridization with a $\mathrm{G} \alpha$ s probe served as a control for polyA ${ }^{+}$RNA loading and confirmed that this message is expressed to a similar extent in the tissues examined. Sizes are given in $\mathrm{kb}$.

cells selectively expressing one or the other subunit in the terminal regions.

Because the VNO has been implicated in the detection of sex pheromones, it is conceivable that it is sexually dimorphic. Consistent with this idea, the VNO of the male mouse contains more neurons than that of the female (Segovia and Guillamon, 1993). However, when we compared the patterns of hybridization of male and female VNO neuroepithelia with $\mathrm{G} \alpha \mathrm{o}$ and $\mathrm{G} \alpha \mathrm{i} 2$ probes, we observed no differences (data not shown).

The patterns of $\mathrm{G} \alpha \mathrm{o}$ and G $\alpha \mathrm{i} 2$ hybridization observed in the $\mathrm{OE}$ are strikingly different from those observed in the VNO (Fig. $1 A)$. G $\alpha$ o appears to be highly expressed in $\mathrm{OE}$ neurons throughout the entire central portion of the OE, where the cell bodies of olfactory neurons are located. More basally located cells, which are likely to be immature neurons or neuronal progenitors (Graziadei and Monti-Graziadei, 1979) (see also Discussion in Caggiano et al., 1994), also show high $\mathrm{G} \alpha$ o expression. G $\alpha \mathrm{i} 2$, which is a ubiquitous mRNA expressed by most cell types, does not appear to be any more highly expressed in OE neurons than in other cell types.

To get a quantitative appreciation of the relative levels of $\mathrm{G} \alpha \mathrm{o}$ and G $\alpha$ i 2 mRNAs in the VNO and OE, G $\alpha$ o and G $\alpha$ i2 probes were hybridized to Northern blots of polyA ${ }^{+}$RNA isolated from these two tissues and from mouse brain and kidney (Fig. 2). The G $\alpha$ o probe hybridized to a similar extent to VNO and OE RNAs; in both cases, two hybridized bands of 3.5 and $4.6 \mathrm{~kb}$ were observed. In brain RNA, the same two bands and an additional band of $\sim 6.9 \mathrm{~kb}$ were recognized by the probe. The single G $\alpha$ o gene can yield splice forms that encode G $\alpha$ o subunits with different C-terminal regions ( $\mathrm{G} \alpha \mathrm{oA}$ and $\mathrm{G} \alpha \mathrm{oB})$ [Murtagh et al. (1994) and references therein]. A comparison of the G $\alpha$ o transcript sizes with those described previously suggests that the large form detected in the brain sample represents $\mathrm{G} \alpha \mathrm{oB}$ and that the two shorter forms represent $\mathrm{G} \alpha \mathrm{oA}$-encoding mRNAs with different untranslated sequences. Partial sequence analyses of two G $\alpha 0$ cDNA clones isolated from the VNO cDNA library indicate that

Table 1. Summary of in situ hybridization studies of G $\alpha$-subunit expression

\begin{tabular}{|c|c|c|c|}
\hline & $\begin{array}{l}\text { Vomeronasal } \\
\text { neurons }\end{array}$ & $\begin{array}{l}\text { Olfactory } \\
\text { neurons }\end{array}$ & $\begin{array}{l}\text { Other nasal } \\
\text { cell types }\end{array}$ \\
\hline $\mathrm{G} \alpha \mathrm{O}$ & $\begin{array}{l}+++ \text { lower layers } \\
\text { of mature }\end{array}$ & $\begin{array}{l}+++ \text { precursor } \\
\text { and mature }\end{array}$ & - \\
\hline G $\alpha i 2$ & $\begin{array}{l}+++ \text { upper lay- } \\
\text { ers of mature }\end{array}$ & $+/-$ mature & + \\
\hline $\mathrm{G} \alpha \mathrm{s}$ & $\begin{array}{l}+++ \text { precursor } \\
++ \text { mature }\end{array}$ & $\begin{array}{l}+++ \text { precursor } \\
++ \text { mature }\end{array}$ & ++ \\
\hline $\mathrm{G} \alpha 13$ & + & + & + \\
\hline Goq & - & - & - \\
\hline $\mathrm{G} \alpha 11$ & + & + & $\begin{array}{l}+ \\
++ \text { cells in } \\
\text { sinus }\end{array}$ \\
\hline $\mathrm{G} \alpha 14$ & - & - & $\begin{array}{l}\text { + respiratory } \\
\text { epithelium }\end{array}$ \\
\hline
\end{tabular}

Sections through the VNO and OE were analyzed for the expression of the indicated $\mathrm{G} \alpha$ subunits by in situ hybridization. + , Hybridization that was above background in the cells indicated; -, No detectable specific hybridization. Except where noted, all cells in the indicated population scored as either + or - The term "precursor" is used to describe cells in regions of the OE or VNO neuroepithelium known to contain neuronal precursors. The term "mature" is used to describe cells located in regions of the neuroepithelia that express OMP, which is expressed in all mature neurons in the VNO and OE.

G $\alpha 0 \mathrm{~A}$ is expressed in the VNO, but they do not rule out the expression of $\mathrm{G} \alpha \mathrm{oB}$ or other, yet uncharacterized splice forms.

As expected from the in situ hybridization studies, the Goi2 probe hybridized to a much greater extent to VNO RNA than to RNA from the other tissues examined. Although a single band of $2.4 \mathrm{~kb}$ was observed in all RNA samples, quantitation of the hybridization signal indicated that G $\alpha \mathrm{i} 2$ mRNA was 10 -fold more abundant in the VNO RNA than in the other RNAs examined. When the same Northern blot was stripped and rehybridized with a $\mathrm{G} \alpha$ s probe, a single $1.9 \mathrm{~kb}$ band was observed in VNO RNA that was similar in intensity to the same band in brain and kidney RNAs.

The high-level expression of only $\mathrm{G} \alpha \mathrm{i} 2$ and $\mathrm{G} \alpha \mathrm{o} \alpha$ subunit mRNAs in VNO neurons suggests that G-proteins containing these $\alpha$ subunits might play major roles in VNO sensory transduction. The high expression of these two molecules in separate subsets of neurons further suggests that there are two distinct mechanisms of sensory transduction used in the VNO.

\section{Patterns of expression of other $\mathrm{G} \alpha$ subunits in the VNO}

$\mathrm{G} \alpha \mathrm{s}$ expression was readily detectable in all cell types in both the VNO and OE by in situ hybridization (Table 1). Unlike most other neurons, sensory neurons of both the VNO and OE are shortlived cells that are replaced continuously from a resident precursor population (Barber and Raisman, 1978; Graziadei and MontiGraziadei, 1979). There appeared to be a somewhat elevated level of expression of $\mathrm{G} \alpha \mathrm{s}$ at the base of the OE and in the dorsal and ventral termini of the VNO. Because these regions of the OE (Graziadei and Monti-Graziadei, 1979; Caggiano et al., 1994) and VNO (Barber and Raisman, 1978) appear to be the locations of neuronal progenitors, it is possible that progenitors in both the $\mathrm{OE}$ and VNO express slightly higher levels of G $\alpha$ s subunits than surrounding cells.

The patterns of hybridization observed with the other $\mathrm{G} \alpha$ subunit probes are summarized in Table 1. G $\alpha 13$ appeared to be 
expressed weakly in all cell types in the VNO and olfactory neuroepithelia. Of the members of the $\mathrm{G} \alpha \mathrm{q}$ class analyzed (G $\alpha \mathrm{q}$, $\mathrm{G} \alpha 11$, and $\mathrm{G} \alpha 14$ ), only $\mathrm{G} \alpha 14$ showed any preferential localization, and this was to the respiratory epithelium of the nasal cavity and the nonsensory epithelium of the VNO. G $\alpha 11$ expression was detectable in both VNO and OE, but it appeared to be very weak. Expression of $\mathrm{G} \alpha \mathrm{q}$ was not evident in either tissue after 2 weeks of autoradiographic exposure. These findings are consistent with our observation that $\mathrm{G} \alpha \mathrm{q}$ and $\mathrm{G} \alpha 11$ did not appear to be abundantly represented in VNO cDNA.

These results argue against the possibility that a $\mathrm{G} \alpha$ subunit belonging to the $\mathrm{G} \alpha \mathrm{s}$ or $\mathrm{G} \alpha \mathrm{q}$ class is directly involved in VNO sensory transduction. Of the $\mathrm{G} \alpha$ subunits identified as being expressed in the VNO, only $\mathrm{G} \alpha \mathrm{O}$ and $\mathrm{G} \alpha \mathrm{i} 2$ are highly expressed in VNO neurons.

\section{AC II is expressed in vomeronasal neurons}

Our previous experiments showed that one subunit of the olfactory CNG channel, which is involved in sensory transduction in OE neurons, is also expressed in VNO neurons. In OE neurons, odor-induced increases in cAMP, which are thought to be mediated by AC III, open CNG channels (Zufall et al., 1994). Although AC III is not expressed in VNO neurons, it is possible that sensory transduction in these cells involves another $\mathrm{AC}$ isoform. To examine this possibility, we asked whether there is any adenylyl cyclase that is highly expressed AC in VNO neurons. Because the olfactory CNG channel can also be opened by increases in cGMP, we also investigated whether there might be a highly expressed guanylyl cyclase in VNO neurons that could mediate increases in cGMP.

To date, at least eight different G $\alpha$ s-activated ACs have been identified (AC I-VIII) that vary in their responses to $\mathrm{G} \alpha \mathrm{i}$ subunits, $\mathrm{Ca}^{2+}$, and G-protein $\beta \gamma$ subunits (Pieroni et al., 1993; Taussig and Gilman, 1995). To determine whether there is an AC that is highly expressed in VNO neurons, we used an approach similar to that we had used to identify G-protein $\alpha$ subunits expressed in those cells. VNO cDNA first was used as template in PCR reactions with degenerate primers matching consensus sequences in ACs. A VNO cDNA library was then screened with the AC PCR product, and hybridized clones were isolated and partially sequenced. Using this approach, two ACs, AC II and AC VII, were identified as being expressed in the VNO. AC III, which is highly expressed in the OE (Bakalyar and Reed, 1990), was not among the clones isolated.

We next used in situ hybridization to examine the expression of AC II and AC VII in the VNO and OE (Fig. 3). The results of these experiments indicate that AC II is highly expressed in VNO neurons, but not in neurons in the OE. With the exception of the extreme termini and the uppermost layer of supporting cells just beneath the epithelial surface, the entire VNO neuroepithelium shows intense hybridization to the AC II probe. This indicates that AC II is expressed in both the $\mathrm{G} \alpha \mathrm{O}^{+}$and $\mathrm{G} \alpha \mathrm{i} 2^{+}$subsets of VNO neurons. AC VII appears to be expressed in nonsensory tissue in the VNO, but not in VNO neurons.

Expression of AC II has been reported previously in the OE, brain, and lung (Feinstein et al., 1991; Mons et al., 1993). Northern blot analysis with the AC II probe (Fig. 4) shows a single hybridizing band in VNO RNA, which is similar in both size (4.7 kb) and intensity to that observed in brain RNA. A much weaker band of the same size is present in OE RNA. A quantitative comparison of the hybridization signals indicates that the AC II mRNA level is at least 10-fold higher in the VNO than in the OE.
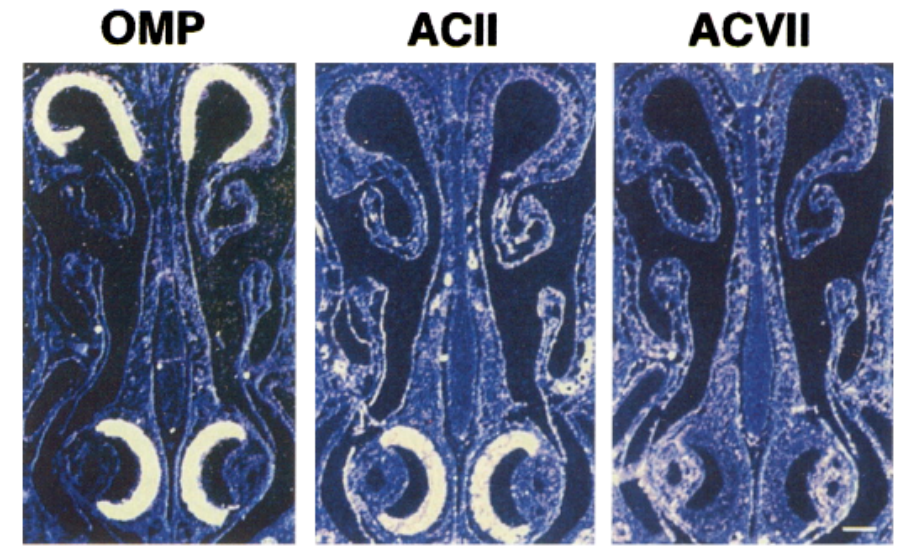

Figure 3. Patterns of expression of AC II and AC VII in the VNO. Coronal sections through the nasal cavity and VNO of the adult mouse were used to analyze the expression of AC II $(A C I I)$ and AC VII $(A C V I I)$. Autoradiographic exposure was for $6 \mathrm{~d}$ (OMP control) or $12 \mathrm{~d}$ (ACs). Photographs were processed using Adobe Photoshop version 3.0 to show hybridization signals in yellow. In this anterior region of the snout, the bilaterally symmetric VNOs can be seen at the base of the nasal septum, and the $\mathrm{OE}$ is restricted to dorsal regions of the nasal cavities. Neither $\mathrm{AC}$ II nor AC VII appears to be expressed in the OE. In the VNO, AC VII hybridization is observed only in glandular tissue. Intense AC II hybridization is observed in neurons throughout the VNO neuroepithelium, but not in the apical-most layer of supporting cells. Scale bar, $250 \mu \mathrm{m}$.

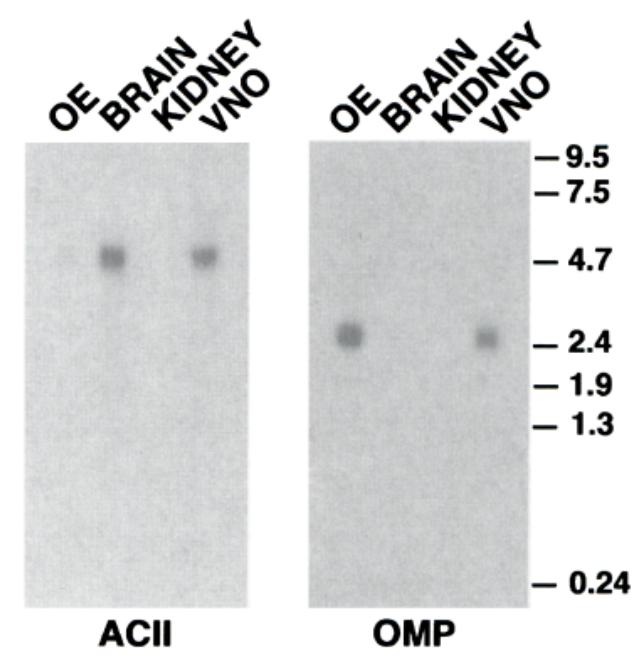

Figure 4. Northern blot analysis of AC II expression. One microgram of polyA $^{+}$RNA obtained from OE, brain, kidney, or VNO was sizefractionated, blotted onto a nylon membrane, and hybridized with an AC II $(A C I I)$ or $O M P$ probe. The similar OMP hybridization signals observed in the VNO and OE RNA samples indicate that they contain approximately equivalent representations of RNAs from mature sensory neurons. The level of AC II RNA in the VNO is similar to that in brain and far exceeds the level of AC II RNA in the OE. Sizes are given in kb.

When the same filter was hybridized to an OMP probe, a roughly comparable signal was observed in the VNO and OE RNAs, which suggests a similar representation of neuronal RNAs in the two samples.

To examine whether there is a guanylyl cyclase (GC) that is highly expressed in VNO neurons, PCR products obtained from VNO cDNA using degenerate primers that match conserved segments in various GCs were first cloned, and unique clones were isolated. Sequence analyses of these clones showed that they 
encoded segments of four different GCs: GC- $\alpha 1$, GC- $\alpha 2$, GC- $\beta 1$, and the natriuretic factor receptor (a transmembrane GC). A very low frequency of hybridized clones was observed when the GC PCR product was used to screen a VNO cDNA library. Consistent with this, in situ hybridization experiments using the four GC clones as probes gave evidence only for the expression of GC- $\alpha 2$, which appeared to be expressed very weakly in the VNO neuroepithelium (data not shown).

The results of these experiments indicate that AC II may play a major role in VNO sensory transduction. The high expression of AC II in both the ${\mathrm{G} \alpha \mathrm{O}^{+}}^{+}$and $\mathrm{G} \alpha \mathrm{i} 2^{+}$subsets of VNO neurons suggests further that sensory transduction in the two subsets may have at least some common components. Our previous finding that the $\mathrm{CNG}$ channel subunit oCNC2 is expressed in both $\mathrm{G} \alpha{ }^{+}$ and $\mathrm{G} \alpha \mathrm{i} 2^{+}$regions of the neuroepithelium also favors this conclusion.

\section{Goo and Goi proteins are enriched in VNO microvilli}

In the nose, sensory transduction occurs in specialized cilia that are extended into the nasal lumen by olfactory neurons (Reed, 1992; Ronnett and Snyder, 1992; Breer et al., 1994; Zufall et al., 1994). Consistent with observations that isolated cilia show odorant-induced increases in cAMP and $\mathrm{IP}_{3}$ (Boekhoff et al., 1990) and that ciliary membranes contain CNG ion channels (Nakamura and Gold, 1987), immunohistochemical studies have localized a number of molecules thought to be involved in olfactory sensory transduction to cilia at the surface of the OE (Koshimoto et al., 1992; Menco et al., 1992; Cunningham et al., 1993; Krieger et al., 1994). VNO neurons resemble olfactory sensory neurons, but they extend microvilli instead of cilia into the VNO lumen (Garrosa and Coca, 1991), which suggests that sensory transduction in the VNO occurs within these microvilli.

The high expression of G $\alpha$ o and G $\alpha$ i2 RNAs in VNO neurons suggests that $\mathrm{G} \alpha \mathrm{o}$ and $\mathrm{G} \alpha \mathrm{i} 2$ may be involved in sensory transduction in the VNO. To investigate this possibility further, we conducted immunohistochemical studies with antibodies specific for $\mathrm{G} \alpha \mathrm{O}$ or $\mathrm{G} \alpha \mathrm{i}$ proteins (antibodies specific for G $\alpha \mathrm{i} 2$ and AC II are not commercially available). Both anti-G $\alpha$ o and anti-G $\alpha$ i antibodies stained the microvillar surface of the VNO neuroepithelium as well as axon bundles underlying the neuroepithelium (Fig. 5). Immunoreactivity was not observed at the surface of the nonsensory epithelium. Furthermore, immunoreactivity was not evident in the dorsal and ventral terminal regions of the VNO neuroepithelium; this is consistent with previous immunohistochemical studies with anti-OMP antibodies, which indicated that these regions lack mature neurons (Monti-Graziadei et al., 1980). Because by morphological criteria the terminal regions do appear to contain supporting cells, which also have microvilli, this argues that the surface immunoreactivity observed throughout the rest of the neuroepithelium is attributable to the presence of $\mathrm{G} \alpha \mathrm{O}$ and $\mathrm{G} \alpha \mathrm{i}$ proteins in the microvilli of VNO neurons.

Our in situ hybridization studies showed that G $\alpha$ o RNAs are also highly expressed in olfactory neurons in the nose. However, in contrast to what was observed in the VNO, and in agreement with previous studies (Shinohara et al., 1992a), we observed no immunoreactivity at the surface of the OE with anti-G $\alpha$ o antibodies (Fig. 5). Strong G $\alpha$ o immunoreactivity was observed only in bundles of sensory axons underlying the OE; neuronal cell bodies in the OE were only weakly immunoreactive. Thus, although neurons in the OE express $\mathrm{G} \alpha \mathrm{o}, \mathrm{G} \alpha \mathrm{o}$ is not enriched in the cilia of these neurons. Anti-G $\alpha$ i antibodies also failed to react with the surface of the OE. However, weak immunoreactivity was
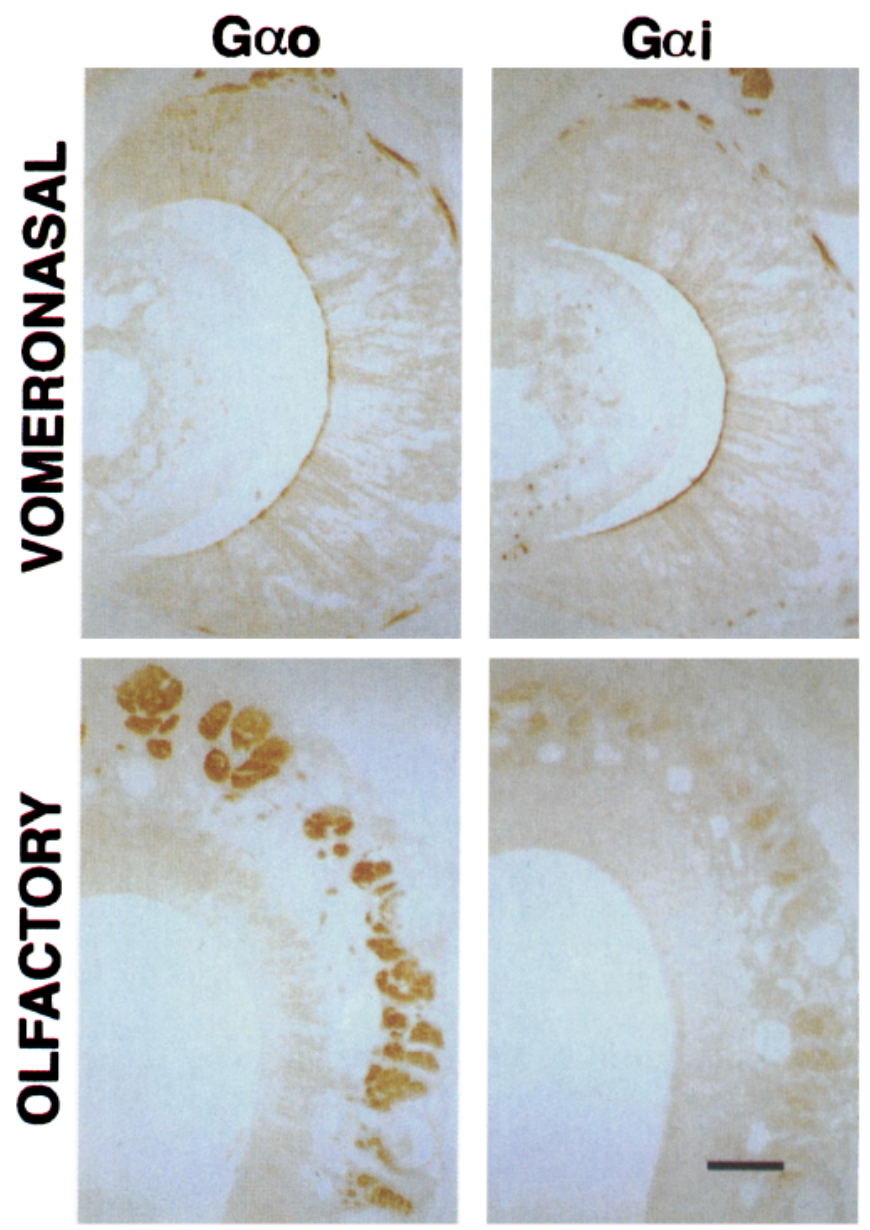

Figure 5. Goo- and Goi-subunit immunoreactivity in the VNO and OE. Coronal sections that included both VNO and OE were immunoperoxidase-stained with antibodies specific for either $\mathrm{G} \alpha \mathrm{O}$ or $\mathrm{G} \alpha \mathrm{i}$ proteins. Both antibodies react with axon bundles underlying the VNO and the OE neuroepithelia. However, intense immunoreactivity is observed at the neuroepithelial surface only in the VNO. This is consistent with a role for Goo and Goi in sensory transduction in the VNO, but not the OE. No brown reaction product was observed when the primary antibodies were omitted from the staining procedure (data not shown). Scale bar, $100 \mu \mathrm{m}$.

observed in axon bundles. These results are consistent with G-proteins containing $\mathrm{G} \alpha \mathrm{o}$ and $\mathrm{G} \alpha \mathrm{i}$ subunits being involved in sensory transduction in the VNO, but not in the OE.

\section{Emergence of the mutually exclusive Goo and Goi2 expression patterns during development}

We next examined the developmental appearance of distinct subsets of G $\alpha \mathrm{O}$ - and $\mathrm{G} \alpha \mathrm{i}$ 2-expressing neurons in the VNO. To do this, we performed in situ hybridization experiments with tissue sections obtained from postnatal day (P) 1, P3, P6, P9, and P13 mice using G $\alpha$ o and G $\alpha \mathrm{i} 2$ probes and an OMP probe (Fig. 6).

Previous studies indicate that the development of the VNO neuroepithelium lags behind that of the OE (Cuschieri and Bannister, 1975). During embryogenesis, mitosis is observed throughout the VNO neuroepithelium. However, in the adult, dividing cells are restricted to the dorsal and ventral termini of the neuroepithelium (Barber and Raisman, 1978). From these termini, cells derived from dividing progenitors migrate along the length of the neuroepithelium, showing no apparent preference for a basal or apical location. By immunohistochemistry, rare $\mathrm{OMP}^{+}$neu- 


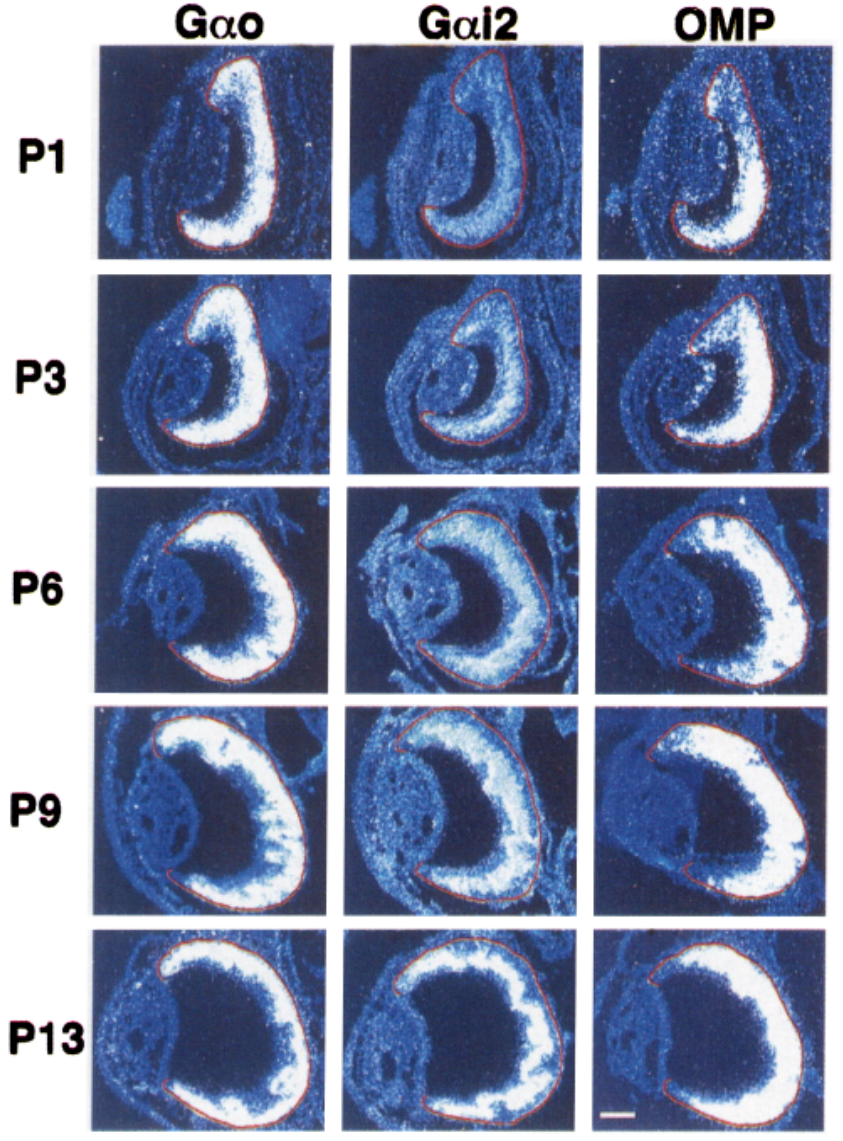

Figure 6. The emergence of distinct $\mathrm{G} \alpha \mathrm{o}$ and $\mathrm{G} \alpha \mathrm{i} 2$ expression patterns in the VNO during development. Consecutive coronal sections through the VNO obtained from $P 1, P 3, P 6, P 9$, and $P 13$ mice were analyzed, in turn, for the expression of $G \alpha o, G \alpha i 2$, and $O M P$ by in situ hybridization. The photographs were processed using Adobe Photoshop version 3.0. A red line demarcates the basal extent of the neuroepithelium and its dorsal and ventral termini. The pattern of OMP hybridization indicates the locations of mature neurons and reveals that the proportion of mature neurons in the VNO neuroepithelium increases from P1 to P13. At P1, intense G $\alpha$ o hybridization is evident throughout the neuroepithelium except in the apical layer of supporting cells adjacent to the epithelial surface. From P6 to $\mathrm{P} 13$, the $\mathrm{G}_{\alpha \mathrm{O}^{+}}$population gradually becomes restricted to a more basal region that occupies $\sim 50 \%$ of the neuroepithelium. Cells expressing high levels of $\mathrm{G} \alpha \mathrm{i} 2$, which appear to be far fewer in number than $\mathrm{G}_{\alpha \mathrm{O}}{ }^{+}$cells at the earlier ages, are concentrated in more apical regions throughout the developmental period examined. By P13, the adult pattern of distinct, spatially localized subsets of $\mathrm{G}_{\mathrm{oO}}{ }^{+}$and $\mathrm{G} \alpha \mathrm{i} 2^{+}$cells is evident. Exposure was for $6 \mathrm{~d}$. Scale bar, $100 \mu \mathrm{m}$.

rons can be detected in the VNO as early as embryonic day 15 (E15) in the rat, but do not become frequent until P4-P5 (Farbman and Margolis, 1980; Monti-Graziadei et al., 1980). From their earliest appearance, $\mathrm{OMP}^{+}$cells show a scattered distribution from the basal to apical extent of the sensory epithelium. The terminal zones, where the neuronal precursors reside (at least in adults), do not show OMP immunoreactivity even in the adult.

In our studies, OMP hybridization was readily detectable in the mouse VNO neuroepithelium at P1, but was less intense in more dorsal and ventral regions of the neuroepithelium than in the central region. Of note, we found no indication that $\mathrm{OMP}^{+}$cells would appear first in the apical or basal regions of the VNO neuroepithelium. This is consistent with our previous observation that at E16, 3 d before birth, the few $\mathrm{OMP}^{+}$cells evident in the VNO are distributed throughout the width of the epithelium
(Sullivan et al., 1995). The intensity of OMP hybridization increased during the first week after birth. However, even at P13 the dorsal and ventral termini of the VNO neuroepithelium, which contain neuronal progenitors and, possibly, immature VNO neurons (Garrosa and Coca, 1991), did not show significant hybridization to the OMP probe.

At P1 and P3, high expression of G $\alpha$ o was evident throughout the VNO neuroepithelium, except in the apical layer of supporting cells. $\mathrm{G}_{\alpha \mathrm{O}^{+}}$cells were present in dorsal and ventral regions that showed low OMP expression, which suggests that neurons express high levels of $\mathrm{G} \alpha \mathrm{o}$ before they become mature enough to express OMP. Consistent with this idea, G $\alpha$ o expression is detectable throughout the VNO neuroepithelium at E18 when only a few scattered $\mathrm{OMP}^{+}$cells are observed (data not shown). At P6 and $\mathrm{P} 9$, the more apical region of the neuroepithelium showed a lower expression of Goo than the more basal region, which suggests the gradual emergence of the adult G $\alpha$ o expression pattern in which only neurons in the lower part of the epithelium express high levels of G $\alpha$ o. At P13 the G $\alpha$ o expression pattern was indistinguishable from that of the adult.

A different developmental pattern was observed for G $\alpha \mathrm{i} 2$ expression. VNO neurons did not show Goi2 hybridization exceeding that of surrounding cells at E18 (data not shown). At P1, regions that showed $\mathrm{G} \alpha \mathrm{i} 2$ expression appeared to be $\mathrm{OMP}^{+}$and were located in the more apical region of the epithelium, as in the adult. This preferential localization of the G $\alpha$ i 2 signal to the upper neuronal layer became even more evident at later time points because of the gradual increase in intensity of Goi2 hybridization from $\mathrm{P} 3$ through $\mathrm{P} 9$.

Thus, at P1 we found G $\alpha$ o hybridization throughout the VNO sensory epithelium even in parts that did not show OMP expression. However, Goi2 expression was confined to more apical regions that were also positive for OMP. Between P1 and P13, this pattern was changed by the gradual increase in intensity of G $\alpha \mathrm{i} 2$ hybridization in the apical part of the epithelium and the gradual decrease in G $\alpha$ o hybridization in the very same region, resulting, by $\mathrm{P} 13$, in the adult pattern of two distinct layers of neurons, one expressing $\mathrm{G} \alpha \mathrm{o}$ and the other expressing $\mathrm{G} \alpha \mathrm{i} 2$.

\section{DISCUSSION}

\section{Sensory transduction in the VNO may involve Gao and $\mathbf{G \alpha i 2}$}

Our previous finding that mouse VNO neurons do not express three presumed components of the $\mathrm{OE}$ sensory transduction cascade (G $\alpha$ olf, AC III, and the CNG channel subunit oCNC1) indicated that sensory transduction in the VNO differs from that in the OE (Berghard et al., in press). However, we also found that VNO neurons do express the second CNG channel subunit, oCNC2. This suggested that VNO transduction, like that in the $\mathrm{OE}$, might involve a G $\alpha$ s-like protein that stimulates cAMP increases. However, studies in snake and turtle implicated $\mathrm{IP}_{3}$ in VNO sensory transduction and suggested the involvement of another G-protein, possibly $\mathrm{G} \alpha \mathrm{o}, \mathrm{G} \alpha \mathrm{i}$, or a member of the $\mathrm{G} \alpha \mathrm{q}$ class (Luo et al., 1994; Taniguchi et al., 1994).

Our results argue against the direct involvement of any member of the $\mathrm{G} \alpha \mathrm{s}$ or $\mathrm{G} \alpha \mathrm{q}$ class of G-proteins in VNO sensory transduction. Although we cloned cDNAs encoding G $\alpha$ s and members of the G $\alpha$ q class from VNO cDNA, none was highly expressed in VNO neurons. Moreover, given the cloning strategy used, it is unlikely that there is a $\mathrm{G} \alpha \mathrm{s}$-like or $\mathrm{G} \alpha \mathrm{q}$-like molecule highly expressed in VNO neurons that was not identified.

Of seven different $\mathrm{G} \alpha$ cDNAs that we cloned from VNO RNA, 


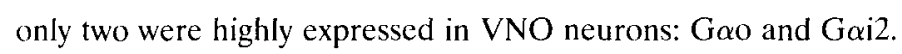
Furthermore, we found that Goo and Goi2 are highly expressed in two separate neuronal subsets that have different locations within the VNO neuroepithelium. Neurons expressing high levels of G $\alpha$ i2 RNA are localized to the apical part of the epithelium, whereas those expressing high levels of G $\alpha$ o RNA are found in a more basal location. These findings are in agreement with a recent immunohistochemical study that examined the expression of G $\alpha$ o and G $\alpha \mathrm{i} 2$ (but not other G-proteins) in the opossum VNO (Halpern et al., 1995). That study suggested that $\mathrm{G} \alpha \mathrm{O}$ and $\mathrm{G} \alpha \mathrm{i} 2$ are present on the cilia, cell bodies, and axons of separate populations of VNO neurons. Our immunohistochemical studies in the mouse indicate further that $\mathrm{G} \alpha 0$ and $\mathrm{G} \alpha \mathrm{i}$ are particularly enriched in VNO microvilli, the presumed site of VNO sensory transduction. The high expression of $\mathrm{G} \alpha \mathrm{o}$ and $\mathrm{G} \alpha \mathrm{i} 2$ but, of importance, not of other $\mathrm{G} \alpha$ subunits, in mouse VNO neurons, and the enrichment of these proteins in microvilli, together support the idea that VNO sensory transduction proceeds via G-protein coupled mechanisms and suggest that the major G-proteins involved are those containing $\mathrm{G} \alpha \mathrm{O}$ and $\mathrm{G} \alpha \mathrm{i} 2$.

The $\mathrm{G} \alpha \mathrm{O}^{+}$and $\mathrm{G} \alpha \mathrm{i} 2^{+}$subsets of VNO neurons conceivably could represent different stages of neuronal differentiation. However, $\left[{ }^{3} \mathrm{H}\right]$ thymidine studies of cell turnover in the adult VNO give no reason to expect a difference in the relative ages of neurons located in $\mathrm{G} \alpha \mathrm{o}^{+}$versus $\mathrm{G} \alpha \mathrm{i} 2^{+}$regions of the neuroepithelium (Barber and Raisman, 1978). Our studies show that during the first week of life $\mathrm{G} \alpha \mathrm{i} 2^{+}$cells are confined to the upper part of the neuroepithelium, as in the adult, but that $\mathrm{G} \alpha \mathrm{o}^{+}$cells are observed throughout the neuroepithelium. There are two possible explanations for this: "immature" $\mathrm{G} \alpha \mathrm{i} 2^{+}$cells coexpress $\mathrm{G} \alpha \mathrm{o}$, but mature $\mathrm{G}_{\alpha \mathrm{i} 2^{+}}$cells do not or, alternatively, cells expressing only $\mathrm{G} \alpha \mathrm{o}^{+}$or $\mathrm{G} \alpha \mathrm{i} 2^{+}$are interspersed in the upper part of the epithelium during the first week of life. It has been proposed that $\mathrm{G} \alpha \mathrm{o}$ is important during axonal growth (Strittmatter et al., 1990, 1994). If so, Gai2 ${ }^{+}$ neurons may express Goo while they are extending axons, but cease to express it once they have formed synapses.

In embryonic rats, 2-deoxyglucose uptake indicative of neuronal activity has been observed in the accessory olfactory bulb, where the axons of VNO neurons synapse (Pedersen et al., 1983). This has prompted suggestions that the VNO is functional in utero. In our studies in the mouse VNO, the adult pattern of $\mathrm{G} \alpha \mathrm{o}$ and $\mathrm{G} \alpha \mathrm{i} 2$ expression was not attained until $\sim 2$ weeks after birth. Similarly, the expression of oCNC2, the CNG channel subunit, is not evident in VNO neurons until $\sim 1$ week after birth, and the morphological maturation of VNO neuronal microvilli is not complete until -2 weeks of age (Garrosa and Coca, 1991). In contrast, odorant receptors and at least several sensory transduction components are expressed in $\mathrm{OE}$ neurons before birth (Sullivan et al., 1995). Together, these observations suggest that the sensory transducing capability of the VNO may not mature until several weeks of age, which is before sexual maturity. Although some pheromonal effects appear to require sensory input from both the VNO and the OE (Keverne, 1983), our data are consistent with a specialized role of the VNO in the sensing of pheromones important to reproductive behavior and physiology.

\section{A possible role for AC II in VNO sensory transduction}

Our studies identify AC II as another likely component of the VNO sensory transduction cascade. Although we cloned several different ACs and GCs from VNO RNA, only one of these, AC II, is highly expressed in VNO neurons. $\triangle \mathrm{C}$ II is expressed in both
$\mathrm{G}_{\alpha \mathrm{O}^{+}}$and $\mathrm{G} \alpha \mathrm{i} 2^{+}$neurons, which indicates that it may be involved in sensory transduction in both neuronal subsets.

Several functional properties distinguish AC II from AC III, which is expressed in OE neurons. (1) AC II, but not AC III, can be stimulated by G-protein $\beta \gamma$ subunits in the presence of low levels of Gos (Tang and Gilman, 1991). (2) AC II, but not AC III, can be stimulated by protein kinase $\mathrm{C}$ (PKC), thereby blocking the inhibitory effects of Gai2 on AC II (Chen and Iyengar, 1993; Yoshimura and Cooper, 1993). (3) AC III can be stimulated by $\mathrm{Ca}^{2+}$, but AC II cannot (Feinstein et al., 1991).

The ability of AC II to be stimulated by $\beta \gamma$ subunits suggests that $\beta \gamma$ released from either $\mathrm{G} \alpha 0$ or $\mathrm{G} \alpha \mathrm{i} 2$ could generate increases in CAMP in VNO neurons. Because $\beta \gamma$ also can stimulate PLC (Sternweis, 1994), there may be a concomitant generation of $\mathrm{IP}_{3}$, giving rise to a situation reminiscent of that in OE neurons, in which odorants can induce increases in both cAMP and $I P_{3}$ (Boekhoff et al., 1990; Ronnett et al., 1993). Diacylglycerol, derived from the stimulation of PLC by $\beta \gamma$ subunits, also could activate $\mathrm{PKC}$ which might, in turn, block the inhibitory effects of G $\alpha \mathrm{i} 2$ on AC II.

The high expression of AC II in VNO neurons provides an important link to our previous observation that VNO neurons express the olfactory CNG channel subunit oCNC2. By analogy with sensory transduction in OE neurons, increases in CAMP in VNO neurons could open CNG channels, thereby causing changes in membrane potential necessary for the generation of action potentials in the sensory axon.

\section{Two transduction pathways in the VNO?}

Given the presence of AC II in all VNO neurons and the possibility that $\beta \gamma$ subunits could cause increases in both cAMP and $\mathrm{IP}_{3}$, why are there two neuronal subsets that express Goo or $\mathrm{G} \alpha \mathrm{i} 2$ ? The ability of $\mathrm{G} \alpha \mathrm{i} 2$, but not G $\alpha \mathrm{o}$, to inhibit ACs (Chen and Iyengar, 1993) suggests that sensory ligands might have opposite effects on CAMP levels in these two subsets. Alternatively, the concentration of $\beta \gamma$ required to stimulate AC II may be higher than the concentration of $\mathrm{G} \alpha \mathbf{i} 2$ required to inhibit this enzyme (Sternweis, 1994). If so, cAMP generation in $\mathrm{G} \alpha \mathrm{i} 2^{+}$cells might require a higher concentration of ligand than in $\mathrm{G} \alpha \mathrm{o}^{+}$cells. $\mathrm{G} \alpha \mathrm{O}$ and Goi2 also might have differential effects that are caused by interactions with different ion channels (Hille, 1994) or different $\beta \gamma$ subtypes (Kleuss et al., 1993). Yet another possibility is that the two G-proteins interact effectively with different types of receptors (Senogles et al., 1990) that are differentially expressed by $\mathrm{G} \alpha \mathrm{O}^{+}$and $\mathrm{G} \alpha \mathrm{i} 2^{+}$cells.

In mammalian OE neurons, different odorants or different concentrations of the same odorant differentially increase $\mathrm{IP}_{3}$ versus cAMP (Boekhoff et al., 1990; Ronnett et al., 1993). Whereas the cAMP increase opens CNG channels and leads to depolarization, the role of $\mathrm{IP}_{3}$ is not presently clear and, furthermore, may differ among species (Ache, 1994). It is conceivable that future studies of sensory transduction in the mammalian VNO will reveal a similarly complex involvement of multiple signal transduction pathways involving cAMP and IP.

What is the functional significance of having two populations of VNO neurons with different transduction pathways? Immunohistochemical studies indicate that VNO axons that synapse in the anterior part of the accessory olfactory bulb (AOB) are $\mathrm{G} \alpha \mathrm{i}^{+}{ }^{+}$, whereas those in the posterior part are $\mathrm{G}_{\alpha \mathrm{O}^{+}}$(Shinohara et al., 1992a). Although these axons need not derive from cells expressing high levels of $\mathrm{G} \alpha \mathrm{i} 2$ and $\mathrm{G} \alpha \mathrm{o}$, respectively (Menco et al., 1994), this is the most obvious possibility. If so, 
it would suggest that an initial segregation of sensory information into two neuronal subsets in the VNO is maintained in the AOB. The two neural pathways conccivably could process different types of sensory information, such as signals relevant to reproduction versus parenting or signals from males versus females. Alternatively, the two pathways might process the same sensory stimuli, but with different response thresholds, or they might be differentially regulated by the hormonal status of the animal.

Note added in proof: Dulac and Axel recently reported the identification of a family of candidate G-protein-coupled pheromone receptors expressed in rat VNO neurons (Cell 1995 83:195206). They noted that there are separate subsets of $\mathrm{G} \alpha \mathrm{O}^{+}$ and G $\alpha \mathrm{i} 2$ VNO neurons in rat and that members of the receptor family thus far are expressed in the $\mathrm{G} \alpha \mathrm{i} 2^{+}$region of the neuroepithelium.

\section{REFERENCES}

Ache BW (1994) Towards a common strategy for transducing olfactory information. Semin Cell Biol 5:55-63.

Bakalyar HA, Reed RR (1990) Identification of a specialized adenylate cyclase that may mediate odorant detection. Science 250:1403-1406.

Barber PC, Raisman G (1978) Cell division in the vomeronasal organ of the adult mouse. Brain Res 141:57-66.

Berghard A. Buck LB, Liman ER (1996) Evidenee for distinct signalling mechanisms in two mammalian olfactory sense organs. Proc Natl Acad Sci USA, in press

Boekhoff I, Tareilus E, Strotmann J, Breer H (1990) Rapid activation of alternative second messenger pathways in olfactory cilia from rats by different odorants. EMBO J 9:2453-2458.

Bray P, Carter A, Simons C, Guo V, Puckett C, Kamholz J, Spiegel A, Nirenberg $M$ (1986) Human cDNA clones for four species of $G \alpha$ signal transduction protein. Proc Natl Acad Sci USA 83:8893-8897.

Breer H, Raming K, Kricger J (1994) Signal recognition and transduction in olfactory ncurons. Biochim Biophys Acta 1224:277-287.

Buck LB (1996) Information coding in the vertebrate olfactory system. Ann Rev Neurosci, in press.

Buck LB, Axel R (1991) A novel multigene family may encode odorant receptors: a molecular basis for odor recognition. Cell 65:175-187.

Caggiano M, Kauer JS, Hunter DD (1994) Globose basal cells are neuronal progenitors in the olfactory epithelium: a linage analysis using a replication-incompetent retrovirus. Neuron 13:339-352.

Cathala G, Savouret J-F, Mendez B, West BL, Karin M, Martial JA, Baxter JD (1983) A method for isolation of intact translationally active ribonucleic acid. DNA 2:329-335.

Chen J, Iyengar R (1993) Inhibition of cloned adenylyl cyclases by mutantactivated Gi- $\alpha$ and specific suppression of type 2 adenylyl cyclase inhibition by phorbol ester treatment. J Biol Chem 268:12253-12256.

Cunningham AM, Ryugo DK, Sharp AH, Reed RR, Snyder SH, Ronnett GV (1993) Neuronal inositol 1,4,5-triphosphate receptor localized to the plasma membrane of olfactory cilia. Neuroscience 57:339-352.

Cuschieri A, Bannister LH (1975) The development of the olfactory mucosa in the mouse: light microscopy. J Anat 119:277-286.

Danciger E, Mettling C, Vidal M, Morris R, Margolis F (1989) Olfactory marker protein gene: its structure and olfactory neuron-specific expression in transgenic mice. Proc Natl Acad Sci USA 86:8565-8569.

Farbman Al, Margolis FL (1980) Olfactory marker protein during ontogeny: immunohistochemical localization. Dev Biol 74:205-215.

Feinstein PG, Schrader KA, Bakalyar HA, Tang W-J, Krupinski J, Gilman AG, Reed RR (1991) Molecular cloning and characterization of a $\mathrm{Ca}^{2+}$ /calmodulin-insensitive adenylyl cyclase from rat brain. Proc Natl Acad Sci USA 88:10173-10177.

Garrosa M, Coca S (1991) Postnatal development of the vomeronasal epithelium in the rat: an ultrastructural study. J Morphol 208:257-269.

Graziadei PPC, Monti-Graziadei GA (1979) Neurogenesis and neuron regeneration in the olfactory system of mammals. I. Morphological aspects of differentiation and structural organization of the olfactory sensory neurons. J Neurocytol 8:1-18.

Halpern M (1987) The organization and function of the vomeronasal system. Annu Rev Neurosci 10:325-362.

Halpern M, Shapiro LS, Jia CP (1995) Differential localization of G proteins in the opossum vomeronasal system. Brain Res 677:157-161.
Hille B (1994) Modulation of ion-channel function by G-protein-coupled receptors. Trends Neurosci 17:531-535.

Keverne EB (1983) Pheromonal influences on the endocrine regulation of reproduction. Trends Neurosci 6:381-384.

Kleuss C, Scherubl H, Hescheler J, Schultz G, Wittig B (1993) Selectivity in signal transduction determined by $\gamma$ subunits of heterotrimeric $G$ proteins. Science 259:832-834.

Koshimoto H, Katoh K, Yoshihara Y, Mori K (1992) Distribution of putative odour receptor protcins in olfactory cpithclium. NeuroReport 3:521-523.

Krieger J, Schleicher S, Strotmann J, Wanner I, Boekhoff I, Raming K, De Geus P, Breer H (1994) Probing olfactory receptors with sequencespecific antibodies. Eur J Biochem 219:829-835.

Lamb TD, Pugh Jr EN (1992) G-protein cascades: gain and kinetics. Trends Neurosci 15:291-298.

Luo Y, Lu S, Chen P, Wang D, Halpern M (1994) Identification of chemoattractant receptors and $G$-proteins in the vomeronasal system of Garter snakes. J Biol Chem 269:16867-16877.

Menco BPM, Bruch RC, Dau B, Danho W (1992) Ultrastructural localication of olfactory transduction components: the $G$ protein subunit Golf $\alpha$ and type III adenylate cyclase. Neuron 8:441-453.

Menco BPM, Tekula FD, Farbman AI, Danho W (1994) Developmental expression of G-proteins and adenylyl cyclase in peripheral olfactory systems: light microscopic and freeze-substitution electron microscopic immunohistochemistry. J Neurocytol 23:708-727.

Mons N, Yoshimura M, Cooper DMF (1993) Discrete expression of $\mathrm{Ca}^{2+} /$ almodulin-sensitive and $\mathrm{Ca}^{2+}$-insensitive adenylyl cyclases in the rat brain. Synapse 14:51-59.

Monti-Graziadei GA, Stanley RS, Graziadei PPC (1980) The olfactory marker protein in the olfactory system of the mouse during development. Neuroscience 5:1239-1252.

Murtagh Jr JJ, Moss J, Vaughan M (1994) Alternative splicing of the guanine nucleotide binding regulatory protein Go $\alpha$ generates four distinct mRNAs. Nucleic Acids Res 22:842-849.

Nakamura T, Gold G (1987) A cyclic nucleotide-gated conductance in olfactory receptor cilia. Nature 325:442-444.

Neer EJ (1995) Heterotrimeric G proteins: organizers of transmembrane signals. Cell 80:249-257.

Neubig RR (1994) Membrane organization in G-protein mechanisms. FASEB J 8:939-936.

Pedersen PE, Stewart WB, Greer CA, Shepherd GM (1983) Evidence for olfactory function in utero. Science 221:478-480.

Pieroni JP, Jacobowitz O, Chen J, Iyengar R (1993) Signal recognition and integration by Gs-stimulated adenylyl cyclases. Curr Opin Neurobiol 3:345-351.

Reed RR (1992) Signaling pathways in odorant detection. Neuron 8:205-209.

Ressler KJ, Sullivan SL, Buck LB (1993) A zonal organization of odorant receptor gene expression in the olfactory epithelium. Cell 73:597-609.

Ronnctt GV, Snyder SH (1992) Molecular messengers of olfaction. Trends Neurosci 15:508-513.

Ronnett GV, Cho H, Hester LD, Wood SF, Snyder SH (1993) Odorants differentially enhance phosphoinositide turnover and adenylyl cyclase in olfactory receptor neurons. J Neurosci 13:1751-1758.

Sambrook J, Fritsch EF, Maniatis T (1989) Molecular cloning: a laboratory manual, 2nd Ed. Cold Spring Harbor, NY: Cold Spring Harbor Laboratory.

Sassoon DA, Garner I, Buckingham M (1988) Transcripts of $\alpha$-cardiac and $\alpha$-skeletal actins are early markers for myogenesis in the mouse embryo. Development 104:155-164.

Segovia S, Guillamon A (1993) Sexual dimorphism in the vomeronasal pathway and sex differences in reproductive behaviors. Brain Res Rev 18:51-74.

Senogles SE, Spiegel AM, Padrell E, lyengar R, Caron MG (I990) Specificity of receptor-G protein interactions. J Biol Chem 265:4507-4514.

Shepherd GM (1988) Neurobiology. New York: Oxford UP.

Shinohara H, Asano T, Kato K (1992a) Differential localization of G-proteins $\mathrm{Gi}$ and $\mathrm{Go}$ in the accessory olfactory bulb of the rat. J Neurosei 12:1275-1279.

Shinohara H, Kato K, Asano T (1992b) Differential localization of $G$ proteins, $\mathrm{Gi}$ and $\mathrm{Go}$, in the olfactory epithelium and the main olfactory bulb of tle rat. Acta Anat 144:167-171.

Sternweis PC (1994) The active role of $\beta \gamma$ in signal transduction. Curr Opin Cell Biol 6:198-203. 
Strittmatter SM, Fishman MC, Zhu X-P (1994) Activated mutants of the subunit of Go promote an increased number of neurites per cell. $J$ Ncurosci 14:2327-2338.

Strittmatter SM, Valenzuela D, Kennedy TE, Neer EJ, Fishman MC (1990) Go is a major growth cone protein subject to regulation by GAP-43. Nature 344:836-841.

Sullivan SL, Bohm S, Ressler KJ, Horowitz LF, Buck LB (1995) Targetindependent pattern specification in the olfactory epithelium. Ncuron 15:779-789

Tang W-J, Gilman AG (1991) Type-specific regulation of adenylyl cyclase by $G$ protein $\beta y$ subunits. Science 254:1500-1503.

Taniguchi M, Kashiwayanagi M, Kurihara K (1995) Intracellular injection of inositol 1,4,5-trisphosphate increases a conductance in mem- branes of turtle vomeronasal receptor neurons in the slice preparation. Neurosci Lett 188:5-8.

Taussig R, Gilnan AG (1995) Mammalian membrane-bound adenylyl cyclases. J Biol Chem 270:1-4.

Wysocki CJ, Meredith M (1987) The vomeronasal system. In: The neurobiology of taste and smell (Finger TE, Silver WL, eds), pp 125-1.50. New York: Wiley.

Yoshimura M, Cooper DMF (1993) Type-specific stimulation of adenylyl cyclase by protcin kinase C. J Biol Chem 268:4604-4607.

Zufall F, Firestein S, Shepherd GM (1994) Cyclic nucleotide-gated ion channels and sensory transduction in olfactory receptor cells. Annu Rev Biophys Struct 23:577-607. 